\title{
Energy Consumption and Carbon Emissions in an Academic Institution in Greece: Can It Become Carbon Neutral?
}

\author{
John Vourdoubas \\ Correspondence: John Vourdoubas, Mediterranean Agronomic Institute of Chania, Crete, Greece. \\ Received: December 6, 2018 \\ Accepted: January 10, $2019 \quad$ Online Published: January 31, 2019 \\ doi:10.11114/set.v6i1.4013 \\ URL: https://doi.org/10.11114/set.v6i1.4013
}

\begin{abstract}
Investigation of energy consumption and carbon emissions in an Academic Institute located in Crete, Greece has been implemented. The possibility of using sustainable energy technologies for covering all its energy needs has been examined. It has been found that the main energy source used was electricity while renewable energies had a small share in the total energy mix. The specific energy consumption has been estimated at $164.96 \mathrm{KWh} / \mathrm{m}^{2}$ and the annual $\mathrm{CO}_{2}$ emissions at $110.64 \mathrm{kgCO}_{2} / \mathrm{m}^{2}$. The combined use of solar thermal energy, solar photovoltaic energy and ground source heat pumps could cover all the annual energy requirements in the Academic Institute zeroing its net carbon emissions. These energy technologies are mature, reliable and commercially used while solar energy is abundant in Crete, Greece. Solar electricity can generate all the electricity required annually with net metering regulations. The investment cost of the required sustainable energy systems to zero the net carbon emissions has been calculated at $184.32 €$ per $\mathrm{m}^{2}$ of its covered surface. It is concluded that if some financial support in the energy investments will be offered then the Academic Institute would become carbon neutral.
\end{abstract}

Keywords: academic institute, $\mathrm{CO}_{2}$ emissions, Crete, energy, Greece, renewable energies

\section{Introduction}

Universities consume energy, usually derived from fossil fuels, and emit greenhouse gases. Due to their pivotal role in the society they should be in the forefront of the global efforts to mitigate climate change. Although various studies concerning specific energy consumption in Academic Institutions have been implemented so far worldwide there is lack of reports concerning their transformation to carbon neutral organizations. Achievement of net zero carbon emissions requires the replacement of fossil fuels and energy derived by fossil fuels with renewable energy sources. Use of various renewable energy technologies should be technically feasible and economically viable. It is necessary for Universities to investigate the possibility to reduce or zero their carbon emissions due to operational energy use. This will facilitate the investment of various renewable energy technologies for energy generation in their premises and the reduction of their carbon emissions. Khoshbankht et al, 2018 reported on energy use characteristics in higher education buildings. The authors have analyzed data from 80 University campus buildings in Australia. They found that buildings used for research had the highest annual energy consumption at $216 \mathrm{KWh} / \mathrm{m}^{2}$ while buildings used for offices had the lowest consumption at $137 \mathrm{KWh} / \mathrm{m}^{2}$. Bernardo et al, 2018 estimated the energy-saving potential in higher education buildings with reference to the building stock of the Polytechnic Institute of Leiria, Portugal. The authors categorized the Academic buildings according to their typology and they implemented energy audits in them. Their results indicated that the potential energy savings vary between 10-34\% in final energy consumption. Lo, 2013 reported on energy conservation in China's higher educational Institutes. The author investigated the energy use in eight (8) Higher Education Institutes (HEIs) in China. He found that HEIs have implemented non-technical interventions to save electricity. However conservation of heat energy was not detected. The author concluded that due to limited financial resources realization of energy saving investments was rather limited. Ma et al, 2015 reported on energy consumption of University campus buildings. The authors stated that energy consumption in various Universities varies significantly. Annual electricity consumption varies from 2000 $\mathrm{KWh} /$ person up to $40000 \mathrm{KWh} /$ person. Annual energy consumption per unit area varies between $250-800 \mathrm{KWh} / \mathrm{m}^{2}$ while annual electricity consumption varies between $80-200 \mathrm{KWh} / \mathrm{m}^{2}$. Carbon emissions vary from $1.4-4 \mathrm{ton} /$ person in European and Asian Universities up to 6-8 ton/person in American Universities. Gul et al, 2015 reported on the relation of occupancy patterns in Academic buildings and their energy consumption. Analyzing the electricity demand data at regular intervals and the occupancy patterns in an Academic building, they did not detect any significant correlation. They found that the building was controlled by a building energy management system which was independent from the occupancy 
patterns. Alshuwaikhat et al, 2008 reported on integrated approaches for achieving campus sustainability. The authors stated that systematic and sustainable approaches for reducing environmental degradation in Academic buildings are generally lacking. The authors concluded that in order to be sustainable a University campus must preserve the environment, stimulate economic growth and improve society. Boonthum, 2018 studied the energy consumption in a public library building. He found that the share of air conditioning to the total energy use was $81.49 \%$, of lighting $10.89 \%$ and of other electric equipment $7.62 \%$. The annual energy consumption in the library was $55.6 \mathrm{KWh} / \mathrm{m}^{2}$, and 23.7 $\mathrm{KWh} /$ person per library user. Berrardi, 2015 reported on building energy consumption in the US, EU and BRIC countries. The author stated that measures adopted in developed countries are insufficient to guarantee a significant reduction in energy consumption in their buildings. He also found that energy consumption in BRIC countries has overcome the total energy consumption in developed countries. Hinge et al, 2004 studied commercial buildings' energy use around the world. The authors stated that there is a trend towards homogenization of the style and types of construction towards more similar "Western style" commercial buildings. They found that annual energy consumption varies between $216 \mathrm{KWh} / \mathrm{m}^{2}$ and 294 $\mathrm{KWh} / \mathrm{m}^{2}$ with an average value at $265 \mathrm{KWh} / \mathrm{m}^{2}$. Energy consumption guides for higher education buildings in United Kingdom have been reported, with targeted annual energy consumption in higher education buildings varying significantly according to the building type. It is lower in office and teaching rooms and higher in catering buildings. Benchmarking values are $75 \mathrm{KWh} / \mathrm{m}^{2}$ for electricity consumption and $182 \mathrm{KWh} / \mathrm{m}^{2}$ for fossil fuels consumption. Ouf et al, 2017 analyzed the energy consumption in school buildings in Manitoba, Canada. The authors stated that school building age had a statistically significant effect on their energy consumption with newer schools consuming less gas but more electricity than older and middle age schools. They also found that middle-aged schools were the largest energy consumers. Vagi et al, 2011 analyzed the energy performance of secondary school buildings in northern Greece. The authors studied the energy consumption in ten high schools of the Prefecture of Evros, Greece during 2001-2005. They found that their mean annual heat energy consumption was $81.50 \mathrm{KWh} / \mathrm{m}^{2}$ while their mean annual electricity consumption was $14.10 \mathrm{KWh} / \mathrm{m}^{2}$. A toolkit for greening Universities, 2013 has been reported. The study states that the primary focus of a University climate action should be on energy management. Energy management includes energy conservation, increase in energy efficiency and promotion of renewable and alternative energy solutions including low carbon energy technologies. Vourdoubas, 2015 studied the creation of zero carbon emissions hospitals in Crete, Greece. The author stated that their annual energy consumption was $366 \mathrm{KWh} / \mathrm{m}^{2}$. He proposed that the combined use of various locally available renewable energy sources for covering all the energy needs in the hospitals could zero their net carbon emissions. Vourdoubas, 2017 reported on the creation of zero carbon emissions office buildings due to energy use in Crete, Greece. The author stated that their annual energy consumption was $186 \mathrm{KWh} / \mathrm{m}^{2}$. He indicated that the use of solar thermal energy, solar photovoltaic energy, solid biomass and high efficiency heat pumps could cover all the energy needs in office buildings in Crete, Greece zeroing their carbon footprint. Deshko et al, 2013 reported on the estimation of energy performance in University campuses in Ukraine. The authors stated that the annual total energy consumption varies between $31.6 \mathrm{KWh} / \mathrm{m}^{2}$ and $608 \mathrm{KWh} / \mathrm{m}^{2}$ with a mean value at $174 \mathrm{KWh} / \mathrm{m}^{2}$. Escobedo et al, 2014 reported on the energy consumption and GHG emissions scenarios of a University campus in Mexico. The authors stated that the covered area in the campus was $1.3 \mathrm{~km}^{2}$ and it was using electricity, LPG and diesel oil. Total annual energy consumption was 83 $\mathrm{KWh} / \mathrm{m}^{2}$ while lighting had the highest percentage in total energy use at $28 \%$. They also mentioned that energy retrofitting of the campus buildings could reduce energy consumption by $7.5 \%$ and $\mathrm{CO}_{2}$ emissions by $11.3 \%$. Luo et al, 2017 estimated the energy consumption in the library building in North China University of Science and Technology. The authors stated that the specific annual energy consumption was $174 \mathrm{KWh} / \mathrm{m}^{2}$ while lighting in the library building had the highest share in energy consumption. Altan et al, 2014 implemented an energy performance analysis of the Academic buildings in Sheffield University, U.K. The authors stated that annual specific energy consumption of gas was 158.74 $\mathrm{KWh} / \mathrm{m}^{2}$, and $75.78 \mathrm{KWh} / \mathrm{m}^{2}$ for electricity. Comparing their results with existing data they concluded that the buildings performed poorly in terms of gas consumption while electricity consumption was satisfactory. Guan et al, 2016 reported on energy usage in a Norwegian University campus. The authors analyzed the last six years of energy data and they estimated the annual heat energy consumption at $99 \mathrm{KWh} / \mathrm{m}^{2}$ and the annual electricity consumption at $206 \mathrm{KWh} / \mathrm{m}^{2}$. Scheuer et al, 2003 reported on the life cycle analysis of a new University building located in the Michigan University campus. The authors mentioned that the covered area of the building was $7300 \mathrm{~m}^{2}$ with a life span of 75 years. They have estimated the life cycle energy consumption at $316 \mathrm{GJ} / \mathrm{m}^{2}$ or $4.21 \mathrm{GJ} / \mathrm{m}^{2}$ year $\left(1170 \mathrm{KWh} / \mathrm{m}^{2}\right.$ year). The share of the embodied energy in the life cycle energy consumption was estimated at $2.2 \%$ during construction and $0.2 \%$ during demolition. Electricity and HVAC consumption accounted for $94.4 \%$ and water heating at $3.3 \%$ of the life cycle energy use. Chung et al, 2014 reported on potential opportunities for energy conservation in existing buildings at a University campus in Korea. The authors estimated the annual energy intensity in the buildings at $223 \mathrm{KWh} / \mathrm{m}^{2}$ compared with an average for Korean University buildings at $210 \mathrm{KWh} / \mathrm{m}^{2}$. They also found potential for energy conservation in the University buildings in the range of 6\%-30\%. Zhou et al, 2013 reported on energy consumption and energy conservation in University buildings in Guangdong province, China. The authors mentioned that there exists a great difference in energy intensity between different types of Universities. Analyzing data from ten Universities over a period of five years, 
they found that electricity consumption varies between $12 \mathrm{KWh} / \mathrm{m}^{2}$ and $35.67 \mathrm{KWh} / \mathrm{m}^{2}$ while annual gas consumption varies between $0.04 \mathrm{M}^{3} / \mathrm{M}^{2}$ and $1.02 \mathrm{M}^{3} / \mathrm{M}^{2}$. They also estimated that there is great potential for energy saving and reduction of $\mathrm{CO}_{2}$ emissions by $25 \%$. Energy consumption in various University buildings around the world varies broadly according to the existing literature from $83 \mathrm{KWh} / \mathrm{m}^{2}$ per year up to $1170 \mathrm{KWh} / \mathrm{m}^{2}$ per year, as presented in Table 1 .

Table 1. Specific energy consumption in University buildings in various countries

\begin{tabular}{llll}
\hline Country & Source & $\begin{array}{l}\text { Specific annual energy consumption } \\
\left(\mathrm{KWh} / \mathrm{m}^{2}\right)\end{array}$ & Notes \\
\hline Australia & Khoshbanht et al, 2018 & $137-216$ & University campuses \\
Worldwide & Ma et al, 2015 & $250-800$ & University campuses \\
Thailand & Boonthum, 2018 & 55.6 & University library building \\
U.K. & Energy efficiency program & 257 & Benchmarkingvalue for Universities \\
Ukraine & Deshko et al, 2013 & 174 & University campuses \\
Mexico & Escobedo et al, 2014 & 83 & University campuses \\
North China & Luo et al, 2017 & 174 & University library building \\
U.K & Altan et al, 2014 & 158.74 & University campuses \\
Norway & Guan et al, 2016 & 305 & University campuses \\
USA & Scheuer et al, 2003 & 1170 & University campuses \\
South Korea & Chung et al, 2014 & 223 & University campuses \\
Crete, Greece & Current work, 2018 & 164.96 & University campuses \\
\hline
\end{tabular}

The aims of the current work are:

1. The estimation of the specific energy consumption and the carbon emissions due to operational energy use in an Academic Institute located in Chania, Crete,

2. The description of the renewable energy technologies which could be used in the Academic Institute for reducing or zeroing its net carbon emissions due to operational energy use, and

3. The sizing and the estimation of the investment cost of the required sustainable energy systems covering all the energy loads in the Institution.

\section{Description of the Academic Institute}

The Academic Institute is a small size higher education and research public organization. Its premises are located in the suburbs of the city of Chania including:

a) Lecturing rooms and offices

b) Various research laboratories,

c) A conference center,

d) Dormitories for the students,

e) A library,

f) A catering facility, and

g) Various traditional residential stone houses used by the participants in the conferences as well as by visiting professors.

Most of its buildings are more than thirty years old, constructed with old building codes and having inefficient thermal insulation. Although the local climate is mild the buildings require a lot of energy for their heating and cooling.

\section{Energy Consumption in the Institute}

The energy sources used currently in the Institute are:

1. Grid electricity for lighting, operation of various devices,machinery, apparatus and for powering the heat pumps used for air-conditioning,

2. Diesel oil for space heating and domestic hot water (DHW) production,

3. LPG for cooking,

4. Solar thermal energy with thermo-siphonic systems with flat plate collectors producing DHW,

5. Solar photovoltaic energy (solar-PVs) generating electricity with nominal power $13.5 \mathrm{KWp}$, and

6. Solid biomass in a wood stove for space heating. 
Climate conditions in the premises of the Institute are presented in Table 2.

Table 2.Climate conditions in Chania, Crete, Greece

\begin{tabular}{lc}
\hline Parameter & Value \\
\hline Latitude & 35.52 .16 \\
Mean annual air temperature & $18.1{ }^{\circ} \mathrm{C}$ \\
Annual precipitation & $550 \mathrm{~mm}$ \\
Mean annual humidity & $67 \%$ \\
\hline
\end{tabular}

Various fuels and energy sources used in the Institute are presented in Table 3.

Table 3. Fuels and energy sources used annually in the Institute ${ }^{1}$

\begin{tabular}{|c|c|c|c|c|}
\hline Energy source & Quantity & $\begin{array}{l}\text { Energy content } \\
\text { (KWh/year) }\end{array}$ & $\%$ of total energy & Energy/fuel Cost (€/year) \\
\hline Electricity & $1569597 \mathrm{KWh}_{\mathrm{el}}$ & 1569597 & 84.96 & 104770 \\
\hline Diesel oil ${ }^{2}$ & $9259 \mathrm{Lt}$ & 97775 & 5.29 & 8539 \\
\hline $\mathrm{LPG}^{3}$ & $22224 \mathrm{Lt}$ & 154235 & 8.35 & 14522 \\
\hline Solid biomass ${ }^{4}$ & $300 \mathrm{Kg}$ & 1463 & 0.08 & 114 \\
\hline Solar-PV & $20200 \mathrm{KWh}_{\mathrm{el}}$ & 20200 & 1.09 & 0 \\
\hline Solar thermal & $4300 \mathrm{KWh}_{\text {th }}$ & 4300 & 0.23 & 0 \\
\hline Total & & 1847570 & 100 & 127945 \\
\hline
\end{tabular}

${ }^{1}$ Average values for the years 2016 and 2017

${ }^{2}$ Heating value of diesel oil, $10.56 \mathrm{KWh} / \mathrm{lt}$

${ }^{3}$ Heating value of LPG, $6.94 \mathrm{KWh} / \mathrm{lt}$

${ }^{4}$ Heating value of biomass $4200 \mathrm{Kcal} / \mathrm{kg}$

\section{Carbon Emissions Due to Operational Energy Use in the Institute}

Use of fossil fuels and electricity generated by fossil fuels in the Institute results in $\mathrm{CO}_{2}$ emissions. Carbon dioxide emissions due to fossil fuels and energy generated by fossil fuels use are presented in Table 4.

Table 4. Annual carbon dioxide emissions due to conventional energy use in the Institute

\begin{tabular}{lcll}
\hline Energy used & $\begin{array}{c}\text { Annual } \mathrm{CO}_{2} \text { emissions } \\
\left(\mathrm{kg} \mathrm{CO}_{2}\right)\end{array}$ & $\begin{array}{l}\text { Annual } \mathrm{CO}_{2} \text { emissions } \\
\left(\mathrm{kg} \mathrm{CO}_{2} / \mathrm{m}^{2}\right)\end{array}$ & $\begin{array}{l}\text { Annual } \\
\text { emissions } \\
\left(\mathrm{kg} \mathrm{CO}_{2} / \text { employee }\right)\end{array}$ \\
\hline Electricity
\end{tabular}

${ }^{1}$ Electricity generation: $0.75 \mathrm{kgCO}_{2}$ per $\mathrm{KWh}$

${ }^{2}$ Diesel oil: $0.27 \mathrm{kgCO}_{2}$ per $\mathrm{KWh}$

${ }^{3} \mathrm{LPG}: 0.23 \mathrm{kgCO}_{2}$ per $\mathrm{KWh}$

${ }^{4}$ Covered area in the Institute: $11200 \mathrm{~m}^{2}$

${ }^{5}$ Number of employees: 70

5. Use of Renewable Energy Technologies for Energy Generation in the Institute

Various locally available renewable energy sources can be used in- or ex-situ at the Institute for electricity, heat and cooling generation, including:

a) Solar thermal energy with solar thermo-siphonic systems with flat plate collectors for DHW production, 
b) Solar-PV energy for electricity generation,

c) High efficiency ground source heat pumps (GSHPs) for heating and cooling.

The abovementioned renewable energy technologies are broadly used in Crete providing heat, cooling and electricity. They are mature, reliable, well proven technologies, their cost-effectiveness has been established, while they are accepted by the local societies. Combined properly, they could cover all the energy consumption in the Institute, zeroing the use of fossil fuels and carbon emissions in its campus. The average annual wind speed in the premises of the Institute is low and the use of wind mills is not suggested. Solid biomass could be also used in the Institute for heat generation. Olive kernel wood is a by-product of olive oil processing industry which is currently used in Crete for heat generation in buildings, in industry and in agriculture. Its price compared with its heating value is attractive. However during its burning flue gases are emitted and the use of alternative heat generation technologies is preferable.Solar thermal cooling could be also used for space cooling. However this technology has not been propagated so far in Crete and the use of GSHPs is preferable.

\section{Requirements for a Carbon Neutral Institution}

In order to zero the net carbon emissions due to operational energy use in the Institute, the following criteria should be fulfilled:

1. All the fossil fuels used for heat generation should be replaced with renewable energy sources preferable locally available, and

2. All the grid electricity used in the Institute should be annually offset with green electricity, preferably solar-PV electricity.

The use of solar-PVs connected into the grid is allowed in buildings and enterprises according to the net-metering initiative which is in force for the last four years in Greece (Greek Ministerial Decree, 2014). Although currently there are limitations regarding the maximum power allowed for the solar-PVs installed with net metering regulations in the Greek islands it is expected that they will be removed after the interconnection of the electric grids of Crete and continental Greece. It should be noted that the share of fossil fuels in grid electricity generation in Crete is approximately $80 \%$ while the remaining $20 \%$ is derived from renewable energies, mainly solar-PV and wind energy. Therefore offsetting all the grid electricity used in the Institute annually with green solar electricity will result in negative carbon emissions in it.

\section{Sizing of Various Sustainable Energy Technologies Covering the Energy Requirements in the Institute}

\subsection{Sustainable energy Technologies Used}

The following sustainable energy technologies are considered for covering all the energy demand in the Academic Institute

1. Solar thermal technology with thermo-siphonic systems and flat plate collectors. It is assumed that they could provide $50 \%$ of the annual requirements in DHW,

2. High efficiency GSHPs with COP equal at 3.5 covering the requirements in space heating and cooling. They could additionally cover the remaining 50\% requirements in DHW,

3. Solar-PV modulus providing annually all the electricity requirements for lighting, operation of various electric equipment and powering the GSHPs. Solar electricity could offset annually all the grid electricity consumed in the Institute.

\subsection{Estimation of the Energy Loads Required in the Institute}

In order to estimate the energy loads required in the Institute the following assumptions have been made

1. All the equipment in the kitchen using LPG will be replaced with electric equipment,

2. Half of the diesel oil used in the Institute is consumed in space heating and the rest in DHW production, and

3. $40 \%$ of the total electricity use is consumed in lighting, operation of various equipment and devices while the rest $60 \%$ for powering the GSHPs.

Energy consumption for heating, cooling, DHW production, lighting and operation of various electric devices in the Institute is presented in table 5. 
Table 5. Energy consumption for heating, cooling, DHW production, lighting and operation of various electric devices in the Institute

\begin{tabular}{lcl}
\hline Energy use & Energy content ( KWh) & \%of total energy use \\
\hline $\begin{array}{l}\text { Electricity used for lighting } \\
\text { and operation of electric }\end{array}$ & 703200 & 38.83 \\
devices & & \\
Electricity used in GSHPs & 1054800 & 58.23 \\
DHW production & 53187.5 & 2.94 \\
Total & 1811187.5 & 100 \\
\hline
\end{tabular}

7.3 Sizing of the Required Sustainable Energy Systems

For sizing the sustainable energy systems required for covering all the energy needs in the Academic Institute the following assumptions have been made

1. Energy consumption in the Institute will remain the same without any improvement in energy efficiency,

2. The annual electricity generation by a solar-PV system in Crete is $1500 \mathrm{KWh}_{\mathrm{el}}$ per $\mathrm{KW}_{\mathrm{p}}$,

3. The annual heat generation by a solar thermo-siphonic system with flat plate collectorsin Crete is $500 \mathrm{KWh}_{\text {th }}$ per $\mathrm{m}^{2}$ of collectors, and

4. In order to cover the peak heat and cooling loads the size of the GSHPs will be double than the size required to cover the average loads.

The size of the sustainable energy systems is presented in table 6 .

Table 6. Size of sustainable energy systems

\begin{tabular}{ll}
\hline Sustainable energy System & Size \\
\hline Solar thermal & $106.4 \mathrm{~m}^{2}$ of solar collectors \\
Solar-PV & $1172 \mathrm{KW}_{\mathrm{p}}$ \\
GSHPs & $424 \mathrm{KW}_{\mathrm{el}}$ \\
\hline
\end{tabular}

\subsection{Capital Cost of the Sustainable Energy Systems}

The capital cost of the sustainable energy systems in the Institute is presented in table 7 . The following assumptions have been made for the estimation

1. The capital cost of the solar-PV system is $1300 €$ per $\mathrm{KW}_{\mathrm{p}}$,

2. The capital cost of the solar thermal system is $300 €$ per $\mathrm{m}^{2}$ of the collectors, and

3. The capital cost of the GSHPs is $1200 €$ per $\mathrm{KW}_{\mathrm{el}}$.

Table 7. Capital cost of the sustainable energy systems

\begin{tabular}{lcl}
\hline System & Cost $(€)$ & $\begin{array}{l}\text { Cost }\left(€ \text { per } \mathrm{m}^{2} \text { of covered }\right. \\
\text { surface })\end{array}$ \\
\hline Solar-PV & 1523600 & 136.04 \\
Solar thermal & 31920 & 2.85 \\
GSHPs & 508800 & 45.43 \\
Total & 2064320 & 184.32 \\
\hline
\end{tabular}

\section{Discussion}

The main energy source used in the Academic Institute in Crete, Greece is electricity, accounting for approximately $85 \%$ of its total energy consumption, while renewable energies contribute only $1.4 \%$ of its annual energy balance. Among renewable energies, solar thermal energy, solar-PV energy and solid biomass are currently used for heat and electricity generation but their contribution to the total energy balance in the Institute is rather limited. Specific total annual energy consumption has been estimated at $164.96 \mathrm{KWh} / \mathrm{m}^{2}$ which is lower than the benchmarking value for British universities which is $257 \mathrm{KWh} / \mathrm{m}^{2}$ while its annual carbon emissions are $110.64 \mathrm{kgCO}_{2}$ per $\mathrm{m}^{2}$. Solar energy is abundant in Crete, Greece and it is already used for heat and power generation. Combined use of solar thermal energy, solar-PV energy and GSHPs could cover all the energy requirements in the Academic Institute located in Crete, Greece zeroing its carbon 
emissions due to energy use. These technologies are mature, reliable and well proven. The legal framework for offsetting grid electricity consumption with solar-PV electricity exists already in Greece allowing the off-site installation of the photovoltaic modulus. A preliminary calculation of the size of the sustainable energy systems required has been made and

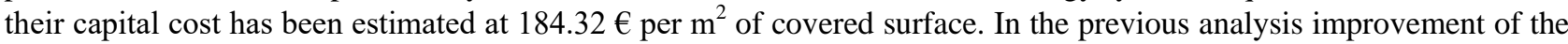
energy efficiency in the Institute has not been foreseen. If though the energy efficiency will be improved the size of the sustainable energy systems required would be smaller. Their overall capital cost, at $2064320 €$, is equal to around fifteen times the current annual cost of the energy consumption in the Institute. The size of the solar thermal system required is small, with an area of flat plate collectors at $106.4 \mathrm{~m}^{2}$, and it can be installed on the terrace of the buildings. The size though of the solar-PV system is large and its installation requires a large surface which is not available in the Institute. However it can be installed outside of the Institute's premises. If financial support in the capital cost of the energy systems is offered then the investment would be profitable. Current study indicates that the sustainable energy technologies required for creating a carbon neutral Academic Institute in Crete, Greece are mature, reliable and commercially used. They could be also economically attractive if a financial subsidy will be offered. Further work should be focused in examining the possibility of using solid biomass burning for heat generation and solar thermal cooling for space cooling in the Institute.

\section{References}

Alshuwaikhat, H. M., \&Abubakar, I. (2008). An integrated approach to achieving campus sustainability: assessment of the current campus environmental management practices, Journal of Cleaner Production, 16, 1777-1785. https://doi.org/10.1016/j.jclepro.2007.12.002

Altan, H., Douglas, J. S., \& Kim, Y. K. (2014). Energy performance analysis of University buildings: Case studies at Sheffield University, U.K., Journal Architectural Engineering Technology, 3(3), 129. https://doi.org/10.4172/2168-9717.1000129

Bernardo, H., \& Oliveira, F. (2018). Estimation of energy saving potential in higher educational buildings supported by energy performance benchmarking: A case study, Environments, 5(85), 1-14. https://doi.org/10.3390/environments5080085

Berrardi, U. (2015). Building energy consumption in US, EU and BRIC countries, Procedia Engineering, 118, 128-136. https://doi.org/10.1016/j.proeng.2015.08.411

Boonthum, E. (2018). Study on energy consumption in library building, Kasem Bundit Engineering Journal, 8(2), 117-130.

Chung, M. H., \& Rhee, E. K. (2014). Potential opportunities for energy conservation in existing buildings on University campus: A field survey in Korea, Energy and Buildings, 78, 176-182. https://doi.org/10.1016/j.enbuild.2014.04.018

Deshko, V. I., \& Shevchenko, O. M. (2013). University campuses energy performance estimation in Ukraine based on measurable approach, Energy and Buildings, 66, 582-590. https://doi.org/10.1016/j.enbuild.2013.07.070

Energy efficiency in further and higher education, Cost effective low energy buildings, Energy consumption guide 54, $\begin{array}{lll}\text { retrieved at } & 12 / 11 / 2018 & \text { from }\end{array}$ http://www.cibse.org/getmedia/f944f3e0-e047-4c62-af85-43f02533f2de/ECG54-Energy-Use-in-Further-Higher-Ed ucation-Buildings.pdf

Escobedo, A., Briceno, S., Juarez, H. Castillo, D., Imaz, M., \& Sheinbaum, C. (2014). Energy consumption and GHG emission scenarios of a University campus in Mexico, Energy for Sustainable Development, 18, 49-57. https://doi.org/10.1016/j.esd.2013.10.005

Greening Universities toolkit, Transforming Universities into green and sustainable campuses, United Nations Environmental Program 2013, Retrieved at 12/11/2018 from

https://europa.eu/capacity4dev/unep/document/greening-universities-toolkit-transforming-universities-green-and-s ustainable-campuses

Guan, J., Nord, N., \& Chen, S. (2016). Energy planning of University campus building complex: Energy usage and coincidental analysis of individual buildings with a case study, Energy and Buildings, 124, 99-111. https://doi.org/10.1016/j.enbuild.2016.04.051

Gul, M. S., \& Patidar, S. (2015). Understanding the energy consumption and occupancy of a multi-purpose Academic building, Energy and Buildings, 87, 155-165. https://doi.org/10.1016/j.enbuild.2014.11.027

Hinge, A., Bertoldi, P., \& Waide, P. (2004). Comparing commercial building energy use around the world, Retrieved at 7/11/2018 from https://aceee.org/files/proceedings/2004/data/papers/SS04_Panel4_Paper14.pdf

Khoshbakht, M., Gou, Z., \& Dupre, K. (2018). Energy use characteristics and benchmarking for higher education 
buildings, Energy and Buildings, 164, 61-76. https://doi.org/10.1016/j.enbuild.2018.01.001

Lo, K. (2013). Energy conservation in China's higher education Institutions, Energy Policy, 56, 703-710. https://doi.org/10.1016/j.enpol.2013.01.036

Luo, R., Han, Y., \& Zhou, X. (2017). Characteristics of campus energy consumption in North China University of Science and Technology, Procedia Engineering, 205, 3816-3823. https://doi.org/10.1016/j.proeng.2017.10.098

Ma, Y. T., Lu, M. Y., \& Weng, J. T. (2015). Energy consumption status and characteristics analysis of University campus buildings, $5^{\text {th }}$ International Conference on Civil Engineering and Transportation, (ICCET 2015), (p.p.1240-1243).

Ministerial Decree, Greek Ministry of Environment, Energy and Climatic Change (YPEKA), 30/12/2014, АПЕН К/А/Ф1/ок.24461, (ФЕКВ' 3583/31.12.2014).

Ouf, M. M., \& Issa, M. H. (2017). Energy consumption analysis of school buildings in Manitoba, Canada, International Journal of Sustainable Built Environment, 6, 359-371. https://doi.org/10.1016/j.ijsbe.2017.05.003

Scheuer, C., Keoleian, G. A., \& Reppe, P. (2003). Life cycle energy and environmental performance of a new University building: modeling challenges and design implications, Energy and Buildings, 35, 1049-1064. https://doi.org/10.1016/S0378-7788(03)00066-5

Vagi, F., \& Dimoudi, A. (2011). Analyzing the energy performance of secondary schools in Northern Greece, in World Renewable Energy Congress 2011, 8-13 May 2011, Linkoping, Sweden.

Vourdoubas, J. (2015). Creation of zero $\mathrm{CO}_{2}$ emission hospitals due to energy use.A case study in Crete, Greece, Journal of Engineering and Architecture, 3(2), 79-86. https://doi.org/10.15640/jea.v3n2a9

Vourdoubas, J. (2017). Creation of zero $\mathrm{CO}_{2}$ emission office buildings due to energy use: A case study in Crete, Greece, International Journal of Multidisciplinary Research and Development, 4(2), 165-170.

Zhou, X., Yan, J., Zhu, J., \& Cai, P. (2013). Survey of energy consumption and energy conservation measures for colleges and Universities in Guangdong province, Energy and Buildings, 66, 112-118. https://doi.org/10.1016/j.enbuild.2013.07.055

\section{Copyrights}

Copyright for this article is retained by the author(s), with first publication rights granted to the journal.

This is an open-access article distributed under the terms and conditions of the Creative Commons Attribution license which permits unrestricted use, distribution, and reproduction in any medium, provided the original work is properly cited. 